provide and remove fear. of defects in this direction. When to this is added the risk introduced by every screw passing through the copper, such as, for example, those necessary for the fixation of the bed, the balance beams from which the radiator system is suspended, \&c., there is at present fear. enough. It was in indicating points such as this that Prof. Benedict's visit was of so much value.

The heat produced within the copper box, carefully prevented from escaping from its surface in the manner described, is carried out in a stream of water constantly driven through the radiator system. The quantity of water passing is varied with the necessities of the moment, and is necessarily much greater when the subject is at work on the ergometer. The water passing is weighed on exit in a meter, and its temperature on entrance and exit observed. The former is practically constant, the latter kept as constant as possible by variation in the rate of water flow. These data form the main items in the statement of heat produced, though other important items, such as the amount of water condensing on the radiator pipes within the chamber, the water evaporated and carried through with the air leaving the chamber, are duly considered and provided for. Thermocouples are placed in the tubes through which the air finds entrance and exit, in quantity 75 litres per minute, so as to ensure the detection of any difference of temperature. Any difference found is corrected by increased heating of the entering air.

In Benedict's calorimeter the air is driven from the chamber through a closed system of tubes back to the chamber again. In this system are interpolated sulphuric acid and soda lime absorbers of a necessarily very large size, determined by the large mass of air in motion per unit of time. The oxygen consumed is made good by admission of oxygen from a cylinder of the compressed gas. In the Sheffield apparatus this will not, at first at least, be attempted. Dried air heated and passer into the chamber will be driven out through a sulphuric acid absorber, no attempt being made to do more than take a determination of the water.

\section{RECENT RESEARCHES IN THE STRUCTURE} OF THE UNIVERSE. ${ }^{1}$

I CONSIDER it an uncommon privilege to lecture on the structure of the universe in the country of the Herschels. Even now their celebrated gauges are unrivalled, and they still form one of the important elements on which any theory of the stellar system must be based. It is well known that the plan of these gauges consisted in directing the telescope successively to different points all over the sky, and simply counting the number of stars visible in the freld.

There is one fact clearly brought out by these gauges to which I must direct your attention. It is that in the outward appearance of our nightly sky, as seen with the telescope, there is a great regularity. In the Milky Way, that belt which we see with the naked eye encircling the whole of the firmament nearly along a great circle, the number of stars, as seen in Herschel's 20 -feet reflector, is enormous. On both sides this apparent croivding of the stars diminishes very gradually and regularly until, near the poles of the Milky Way, we come to the poorest parts of the sky.

Let us look at this phenomenon somewhat more closely. If we direct our telescope first towards the part of the Milky Way near Sirius, and if from there we gradually work up towards the North Pole of the Milky Way in the constellation called the Hair of Berenice, we shall clearly perceive this gradual and regular change in the number of stars. Now if we repeat the same process, beginning from some other point of the Milky Way, say in Cassiopeia or the Southern Cross, we shail find that not only is there a similar gradual change, but we shall approximately go through the same changes.

At the same distance from the Milky Way we shall find, approximately, the same number of stars in the field of the telescope. Put in other words, the richness of stars

1 Discourse delivered at tue Royal Institution on Friday, May 22, by Prof. J. C. Kapteyn.

NO. 2018 , VCL. 781 varies regularly with the galactic latitude; it varies relatively little with the galactic longitude.

Imitating most of the investigators of the stellar system, we will therefore disregard the longitude and keep in view only the changes with the galactic latitude. In reality this comes to being satisfied with a first approximation. For, in reality, there are differences in the different longitudes, especially in the Milky Way itself. But even here the differences are not so great as seems commonly to be supposed. There is every reason to believe, therefore, that our approximation will be already a toler bly close one.

\section{Real Structure.}

Meanwhile, what the Herschel gauges teach us is only relative to the outward appearance of the sky. What is the real structure of the stellar world? If we see so many stars in the field, with the telescope directed to the Milky Way, is it because they are really more closely crowded there, as Struve thinks, or is the view of the older Herschel correct, who imagined that the greater richness is simply a consequence of the fact that we are looking in deeper layers of stars; that our universe is more extensive in the Milky Way than it is in other directions?

Imagine that we could actually travel through space. For instance, imagine that first we travel in the direction of the constellation Cassiopeia. If we travel with the velocity of light, not so very many years would pass before we get near to some star. Proceeding on our journey for many, many more years, always straight on, we will pass more stars by and by. How will these stars look thus viewed from a moderate distance-say, from a distance as that of the sun? Will they all be found to be of equal luminosity, as Struve practically assumed? And in this case are they as luminous as our sun, or more so, or less so? Or are they unequal? If so, how many of them are brighter than our sun, how many fainter? Or, to be more particular, how many per cent. of the stars are ro, too, rooo, \&c., times more luminous than our sun? How many are equal to the sun, or ro, roo times fainter? In a few words: What is the nature of the mixture? or, lastly, what is the mixture law of the system of the stars?

Furthermore, in travelling on, shall we find the stars in reality equally thickly, or rather thinly, crowded everywhere? Or shall we find that after a certain time, which may be many centuries, they begin to thin out, as a first warning of an approaching limit of the system? Is there really such a limit, which, once passed, leads us into abysses of void space?

Herschel thought there was such a limit, and even imagined that his big telescope penetrated to that limit; that is, he assumed that his telescope made even the remotest stars visible. On this supposition is based his celebrated disc theory of the system.

Again, we may condense these questions in this single query: How does the crowding of the stars, or the stardensity, that is, the number of stars in any determined volume (let us say in a cubic light century), vary with the distance from our solar system?

But there is more. We supposed that our journey went straight on in the direction of Cassiopeia, which is in the Milky Way. What if our journey is directed to the Pleiades, which are at some distance from that belt, or to the Northern Crown, which is still further, or to the Hair of Berenice, which is furthest of all from the Milky Way? For different regions equally distant from the galaxy we have seen that outward appearances are the same. We may admit, with much probasility, that in space, too, we would find little difference. Summing up, the problem of the strudture of the stellar system in a first approximation comes to this :-

To determine, separately for regions of different galactic latitude, in which way the star-density and the mixture vary with the distance from the solar system.

I think that there is well-founded hope that, even perhaps within a few years, sufficient materials will be forthcoming which will allow us to attack the problem to this degree of generality, with a fair chance of success. At the present moment, however, our data are yet too scanty for the purpose. Still, they will be sufficient for the derivation of what must be in some sort ajerage con- 
ditions in the system. The method of treatment will not be essentially different from that which will be applied later to the more general problem, but we have provisionally to be content with introducing the two following simplifications :-

(I) We will assume that the mixture is the same throughout the whole of the system.

(2) We will not treat the different galactic latitudes separately.

The consequence will be that the resulting variations of density to which our discussion leads will not represent the actual variations which we would find if we travelled in space in any determined fixed direction, but a variation which will represent some average of what we would find on all our travels if we successively directed them to different regions, of the sky.

Our present problem will thus be confined to finding out :-

(a) The mixture law.

(b) The mean star-density at different distances from the solar system.

If time allows, I will, at the end of this lecture, say a few words on the restrictions introduced, and the way to get rid of them.

As it is not given to us to make such travels through space as here imagined, we have to rely on more human methods for the solution of our problem.

\section{Determination of Distance.}

It is at once evident that there would be no difficulty at all if it were as easy to determine the distance of the stars as it is to determine the direction in which they stand. For in that case the stars would be localised in space, and it would be possible to construct a true model from which the peculiarities of the system might be studied.

It is a fact, however, that, with the exception of a hundred stars at most, we know nothing of the distances of the individual stars.

What is the cause of this state of things? It is owing to the fact that we have two eyes that we are enabled not only to perceive the direction in which external objects are situated, but to get an idea of their distance, to localise them in space. But this power is rather limited. For distances exceeding some hundreds of yards it utterly fails. The reason is that the distance between the eyes as compared with the distance to be evaluated becomes too small. Instruments have been devised by which the distance between the eyes is, as it were, artificially increased. With a good instrument of this sort distances of several miles may be evaluated. For still greater distances we may imagine each eye replaced by a photographic plate. This would even already be quite sufficient for one of the heavenly bodies, viz. for the moon.

At one and the same moment let a photograph of the moon and the surrounding stars be taken both at the Cape Observatory and at the Royal Observatory at Greenwich. Placing the two photographs side by side in the stereoscope, we shall clearly see the moon "hanging in space," and may evaluate its distance.

But already for the sun and the nearest planets, our next neighbours in the universe after the moon, the difficulty re-commences.

The reason is that any available distance on the earth, taken as eye-distance, is rather small for the purpose. However, owing to incredible perseverance and skill of several observers, and by substituting the most refined measurement for stereoscopic examination, astronomers have succeeded in overcoming the difficulty for the sun. I think we may say that at present we know its distance to within a thousandth part of its amount. Knowing the sun's distance, we get that of all the planets by a wellknown relation existing between the planetary distances.

But now for the fixed stars, which must be hundreds of thousands of times further removed than the sun. There evidently can be no question of any sufficient eyedistance on our earth. Meanwhile, our success with the sun has provided us with a new eye-distance, 24,000 times greater than any possible eye-distance on the earth. For now that we know the distance at which the earth travels in its orbit round the sun, we can take the diameter of its orbit as our eye-distance. Photographs taken at epochs six months apart will represent the stellar world as seen from points the distance between which is already best expressed in the time it would take light to traverse it. The time would be about sixteen minutes.

However, even this distance, immense as it is, is on the whole inadequate for obtaining a stereoscopic view of the stars. It is only in quite exceptional cases that photographs on a large scale - that is, obtained by the aid of big telescopes-show any stereoscopic effect for fixed stars. By accurate measurement of the photos we may perhaps get somewhat beyond what we can attain by simple stereo scopic inspection, but, as we said a moment ago, astronomers have not succeeded in this way in determining the distance of more than a hundred stars in all.

How far we are still from getting good stereoscopic views appears clearly from the stereoscopic maps which your countryman, Mr. Heath, constructed, making use of the data obtained in the way presently to be considered. In order to get really good pictures, he found it necessary to increase the eye-distance furnished by the earth's orbit 19,000 times. Are there, then, no means of still increasing this eye-distance?

\section{Motion of Solar System through Space.}

There is one way, but it is a rather imperfect one. Sir William Herschel was the first to show, though certainly his data were still hardly sufficient for the purpose, that the whole of the solar system is moving through space in the direction towards the constellation of Hercules. Later observations and computations have confirmed Herschel's conclusions, and we have even been able of late to fix with some precision the velocity of this motion, which amounts to 20 kilometres per second. This velocity is a 15,000 th part of the velocity of light. In the 150 years elapsed since Bradley determined for the first time the position of numerous stars with modern precision, the solar system must thus have covered a distance of exactly a hundredth part of a light-year, i.e. we are thus enabled to make pictures of the sky as seen from points of view at a mutual distance of a hundredth of a light-year. Our eye-distance of sixteen light minutes is thus increased more than 300 -fold. True, this distance falls still considerably short of that adopted by Heath, but it appears that, for a considerable part of the stars, it is, though not nearly so great as might be desired, still in a certain way sufficient.

There is, however, a difficulty in the way, which prevents our pictures from giving a stereoscopic view of the stars at all, and thus prevents the determination of the distance of any star in this manner. The difficulty is that the changed directions in which, after the lapse of 150 years, we see the stars is not exclusively the consequence of the sun's motion through space, but is due also to a real motion of the stars themselves. The two causes of displacement which, in the case that we take the diameter of the earth's orbit as eye-distance, are separable by means of a simple device, become inseparable in the present case. In order to see whether this difficulty be or be not absolutely insuperable, I will take a parallel case on the earth.

At a certain distance we observe a cloud of insects hovering over a small pond. In order to evaluate the distance separating the insects from our eye, suppose that we make a photograph; then, after a few seconds, a second one from a slightly different standpoint. It must be evident that even if we have used an instrument which clearly shows the individual insects, the two pictures put in the stereoscope will not furnish a stereoscopic view of them individually; on the contrary, the picture as seen in the stereoscope will be perfectly chaotic. The reason, of course, is that in the interval between the taking of the two photographs the insects have moved. Does it follow that no evaluation of the distance can be obtained?

The answer must be, of any individual insect, no; but of the cloud, as a whole, we can evaluate its distance provided that the cloud, as a whole, has not moved; or, expressed more mathematically, provided that the centre of gravity of the cloud has not moved, we can derive the average distance ${ }^{2}$ of all the insects. We shall be sure of

1 The expression average distance ought, strictly speaking, to be replaced by the distance corresponding to the average parallax. For clearness sake
I have ventured here and in what follows to substitute one expression for th other.

NO. 2018, VOL. 78] 
the immobility of the centre of gravity if we know that the direction of the motions of the insects is quite at random; but this is by no means required. The motion may be preferentially in a horizontal plane or along a determined line, say along: the longer axis of the pond, provided only that the motions in any two opposite directions are equally frequent.

Not only that, even if the cloud, as ai whole, is not immovable, we are not necessarily helpless. For, if the insect cloud and the photographer were both on a sailing vessel, circumstances would be the same as on the mainland, though now the cloud is in motion. Only, instead of the absolute displacement of the photographic apparatus, we must know the displacement relative to the ship, or rather relative to the insect-cloud. This, then, finally is the real thing. wanted. We may obtain the distance of the insect-cloud, or, what comes to the same, the average distance of its members, as soon as we are able to find out the displacement of our point of view with regard to the centre of gravity i of the cloud.

Our case is much the same in the world of the stars.

We shall be able to determine the average distance of the members of any arbitrary group of stars provided that we can find the motion of the solar system, both in amount and in direction, relative to the centre of gravity of the group.

Now, astronomical observations such as those which led the elder Herschel to his discovery of : the solar motion through space enable us to determine the direction of the sun's motion relative to such groups as the stars of the third, fourth, \&c., magnitude. Spectroscopy enables us to determine the amount of that motion.

We :must be able, therefore, to find out the average distance of the stars in these groups. For other groups, such as the: stars having an apparent centennial motion of $10^{\prime \prime}, 20^{\prime \prime}$, \&c., there is a difficulty. Still, however, we have succeeded in overcoming this difficulty by a somewhat indirect process, and pressing into service the stars of which the individual distances are known. This, then, is the upshot of astronomical work on the distances.

\section{What we know about Star-distance.}

By direct measurement we know the distance of some hundred individual stars.

For the rest.we know the average distance ot any fairly numerous group of stars of determinate apparent magnitude and apparent motion. ${ }^{1}$

The question is, Can this imperfect knowledge of the distances be considered as in any wise sufficient for obtaining an 'insight into the real arrangement of the stars in space? - I think it can, and. I will now try to show in what manner.

(To be continued.)

\section{UNIVERSITY AND EDITCATIONAL INTELIIGENCE.}

OxFORD.--The following is the text of the speeches delivered by Prof. Love in presenting recipients of the degree of D.Sc. honoris causa at the Encænia on June $24:-$

\section{Fulgence Raymond.}

Antequam de huius viri laudibus loquar, breviter dixerim centum fere abhinc annos celeberrimam medicorum scholam Parisiis exstitisse, eandem sæculo proximo exeunte, Charcotio familiam ducente, maxima. laude floruisse. Charcotio successit. Fulgentius Raymond, magistro discipulus clarissimus : quo rem feliciter navante valetudinarium Salpetriense, in quo quasi in aliquo orbis terræ theatrc partes primarias agit, omnium in se ora convertit. Hic excultæ sunt plurimæ rationes, quæ ex eo

I At the present moment some ubjection might certainly still be made against the generality of this statement. In fact, the scircity of spectroscopic data is the cause that, though the determination of the solar motion separately for such groups as the stars of determinate magnitude and proper motion is quite possible, it has not yet been carried through. As a consequence, the results used in what follows still rest on the assumption that the centres of gravity of all the group; considered are at rest relative to each other. That this assumption must be probably true follows from the near identity of the diriction of t'e sun's motions, furnished by the several groups.

NO. 2018, VOL. 78] pendent quod ni præ se ferunt qui affirmant posse corpori ægrotantis ipsam mentem mederi.: quo in genere hic noster, dum de cerebri et de medullæ spinalis natura docte luculenterque disserit, laudem maximam consecutus est. Felicissimum profecto amicitiæ inter Britanniam et Galliam reconciliatæ documentum duco, quod hic vir de medicorum apud Gallos insignissimorum usu et rationibus magno medicorum nostrorum conventu. Londinii nuper contionatus est.

\section{Jethro Justinian Harris teall.}

Descriptioni Geologicæ, impensis publicis faciendæ, quæ saxorum solo Britannico subiectorum naturam, qua vi conflata sint, quo tempore coorta exquirit, præfectus est Jethro Justinianus Harris Teall. Qui vir, quo melius rem tantam conficeret, non in uno tantum genere laudis excellit : neque enim solum rationes quæ latissime patent animo comprehendere, sed etiam minutissima quæque et observare et repræsentare miro modo potest. His artibus usus, cum saxorum diversissimorum compages scrutaretur, omnia e montibus vi ignea liquefactis exorta esse cognovit: idem mutationes quas hæc saxa patiuntur gravi pondere oppressa subtilissime enarravit. Quo ingenio, qua peritia in hoc genere usus sit declarat ille liber de Insularum Britannicarum Petrologia conscriptus, quem aureolum esse ego iure dixerim.

\section{JAMES WARD.}

Inter Psychologos nemo: clarior est quam Jacobus Ward, qui Psychologiam, cuius scientiæ proprium sit singulorum: sensus tractare, non ex alia scientia pendere sed sui iuris esse constanter asseverat : cuius in ore semper est vox illa "Ego sum. Nihil mihi hoc yerius?" Qui vir ita priorum repertis usus est ut erroribus vitatis longius progrederetur : idem si quid boni usquam invenisset non aspernatus novam, quæ latissime pateret, rationem excogitavit et necessitudinem quandam inter mentem nostram et rerum naturam intercedere docuit. Psychologiam etiam cum aliis scientiæ. generibus artissime cohærere monstravit et omnibus qui cognoscendi ratio quæ sit investigant vel hominum moribus student utilissimam. esse contendit. Neque ei satis erat huic scientiæ novum quasi fundamentum præber, sed muttorum diverso in genere philosophorum opiniones reprehendit: quæ omnia in libro paucos abhinc annos edito pervulgata cum is qui rerum naturæ investigandæ operam dant tum is qui philosophiæ potissimum, incumbunt maxime profuerunt.

Manchester.-Lord Morley, Chancellor of the University, has nominated the following as recipients of honorary degrees on the occasion of his installation, which has been fixed for July 9 :- the Right Hon. A. J. Balfour, Mr: E. J. Broadfield (treasurer of the University), $\mathrm{Mr}$. Andrew Carnegie, Lord Courtney of Penwith, Lord Curzon of Kedleston, Sir Ed. Donner, Bart., Dr. A. M. Fairburn (principal of Mansfield College, Oxford), Sir Frank Forbes Adam (chairman of the university council), the Right Hon. R. B. Haldane, Sir H. F. Hibbert (chairman of the Lancashire Education Committee), Sir W. H. Houldsworth, Bart., Prof. Henry Jackson, Sir William Mather, Mr. J. Cosmo Melvill (donor to the Manchester Museum of the Cosmo-Melvill herbarium), and Sir Edward Maunde Thompson. In addition, the following honorary degrees will be conferred:-LL.D., Mr. A. J. Evans (keeper of the Ashmolean Museum) and Mr. William Farrer (editor of the "Victoria County History of Lancashire"; D.Sc., Emeritus Prof. Gamgee.

Mr: R. E. Slade has been elected to a Gartside travelling scholarship. Dr. Hans Geiger has been re-appointed to the Harling fellowship in physics.

The Countess of Bective will present the prizes at the Horticultural College, Swanley, Kent, on Tuesday, July I4. Sir John Cockburn, K.C.M.G., will take the chair at 4 p.m.

WE are glad to be able to announce that a petition for a charter for a University of Bristol has been sent to the Privy Council. A concordat is being arrived at between University College, Bristol, and the Merchant Venturers Society, which has for many years been identified with work of technical and secondary education in the city. The most liberal support for the University scheme tras 